\title{
Efficient ways to develop reading comprehension skills
}

Chiș Olga, Grec Claudia 


\title{
Efficient ways to develop reading comprehension skills
}

\author{
Chiș Olga ${ }^{a *}$, Grec Claudia ${ }^{b}$ \\ ${ }^{a}$ Faculty of Psychology and Educational Sciences, Babeș-Bolyai University, 7 Sindicatelor Street, Cluj-Napoca, 400029, Romania \\ ${ }^{b}$ Babeş-Bolyai University Cluj-Napoca, 7 Sindicatelor Street, 400029, Romania \\ *Corresponding author: olga_marcus@yahoo.com
}

\section{Abstract}

Keywords:

skills; comprehension; read text; teaching strategies; interactive methods
In the past few years, there is an increasing emphasis on a pedagogy for skills. One of the most complex skills, which is formed from the first years of schooling, is the reading-writing skill. Students begin first grade with high ex-pectations towards reading, with the desire to discover the mysteries of the letters. Reading requires - in addition to the ability to decode a written text and the comprehension of the reading identifying the meaning of the word and the message to be transmitted. Failure in this sense has repercussions on the formation of the personality of the child. Teachers in the classroom are mainly concerned with the prevention of any difficulties that may arise in the formation of the ability to read and write, trying to come up with ways to intervene in the context of the education-al process. This paper aims to find ways of training and developing reading comprehension methods that can be applied in the teaching and learning activities. This is particularly important for understanding and responding to the needs of each student in the class.

\section{Zusammenfasung}

\section{Schlüsselworte:}

Kompetenzen;

Verständnis; Text

lesen;

Unterrichtsstrategien; interaktive Methoden.
In den letzten Jahren wurde zunehmend Wert auf eine Pädagogik für Kompetenzen gelegt. Eine der komplexesten Kompetenzen, die von den ersten Schuljahren gebildet wird, betrifft das Lesen und Schreiben. Die Schüler beginnen die erste Klasse mit hohen Erwartungen an das Lesen, mit dem Wunsch, die Geheimnisse der Buchstaben zu entdecken. Das Lesen erfordert - neben der Fähigkeit, einen geschriebenen Text zu dekodieren und das Verständnis des Lesens - die Identifizierung der Bedeutung des Wortes und die gesendete Nachricht. Ein Versagen in diesem Sinne hat Auswirkungen auf die Persönlichkeitsbildung des Kindes. Die Lehrer im Klassenzimmer befassen sich hauptsächlich mit der Vermeidung von Schwierigkeiten, die bei der Bildung der Lese- und Schreibfähigkeit auftreten können, und versuchen, Wege zu finden, um im Kontext des Bildungsprozesses ein-zugreifen. Dieses Papier zielt darauf ab, Wege zu finden, um Leseverständnismethoden $z u$ trainieren und zu entwickeln, die in den Lehr- und Lernaktivitäten angewendet werden können. Dies ist besonders wichtig, um die Bedürfnisse jedes Schülers in der Klasse zu verstehen und darauf zu reagieren.

\section{Introduction}

In the past few years, there has been an increasing emphasis on a pedagogy for skills. (Dulamă \& Ilovan, $2015,2017)$ One of the most complex skills, which is formed from the first years of schooling, is the readingwriting skill. This paper aims to find ways of training and developing reading comprehension methods that can be applied in the teaching and learning activities and in the assessment process. Nowadays, when information is conveyed in a variety of ways, the ability to read is essential and has value. We are surrounded by written materials (such as books, newspapers, magazines, books, advertisements, instant messages, web pages, etc.), so that reading takes up a leading role both in your professional life, as well as in the society. Reading requires the coordination of many strategies, abilities and skills: decoding the written text, comprehending the text read and the ability of the expression to the document. Thus, even in the early years of schooling, as children are learning to read, reading becomes a fundamental skill as it is a cognitive instrument that is necessary in the acquisition of knowledge later on. The development of this competence is highly complex and it is a challenge for teachers, because not all children are able to develop the necessary reading skills or the appropriate comprehension skills. We also point out the fact that reading requires a higher level of inconsistencies in the interpretation and contribute to the development of vocabulary, communication, imagination, creativity and, implicitly, of school performance.

\section{Problem Statement}

Gardner argues that each individual possesses a unique combination of nine types of intelligence according to the Theory of Multiple Intelligences (linguistic/verbal, logical- 
mathematical, musical/ rhythmic, visual-spatial, naturalistic, bodily-kinesthetic, intrapersonal, interpersonal, existential). This combination acts in a complementary, compensatory and co-ordinated manner. Therefore, in order to improve the training, there is need for a pedagogy that is interactive, varied, and individualized so as to take into account the psychological characteristics, the age of the students, their learning styles and their educational needs. (Bocos, 2013, p. 143) Considering the potential of each student and his/her learning style, the content will be the same for all students, but the mode of transmission will be different, in order to achieve the targeted objectives and to focus on the individual work performed by each student. We provide a few examples of differentiated instructional strategies that need to be taken into account: the adequacy of the teaching methods and techniques with regard to the content that is to be offered and the potential of the students, the selection of appropriate resources, curriculum and organisation of students' work. Also, the notions, the concepts of the data will be logical and praxiological. It is important to note that the teacher plays the role of a mentor and of a guide of the learning activities and of the development process of students' capacities and skills.

\section{Research Questions}

As a result of the studies carried out in recent years relating to the differences in the formation of the text reading comprehension skills, it should be pointed out that, in some cases, the comprehension deficit cannot be attributed to the difficulties of decoding; also, a good decoding can co-exist with a poor comprehension ability. It is considered that there is a single system of processing, both in comprehension of the text read, as well as in the comprehension of the oral language. The consistency of the application of the appropriate strategies for learning to read and write will strengthen the development of skills for the comprehension of the written text. Over the years, over generations of students, it was found that there were students whose reading was cursive and without other lexical problems, but they failed to answer all the inferential questions asked, the comprehension of the text being deficient.

\section{The research question is:}

Is the development of reading comprehension skills favored by the use of teaching strategies appropriate to students' particularities?

\section{Purpose of the study}

The purpose of this psycho-pedagogical experiment is to highlight the need to understand the mechanisms involved in the activity of comprehending a text read and the specific students' learning characteristics in order to offer the teacher the possibility to adapt one's teaching style to students' learning styles students and to promote the comprehension of a read text. When the transmitted message reaches the student in ways that suits one's needs, when it is in accordance with one's learning style, it is easily recognized by the brain, the assimilation of the knowledge being easily achieved and thus, the ability to interact with the text and to make the necessary connections between its elements increases.

\section{The psycho-pedagogical experiment}

The psycho-pedagogical experiment was carried out for a school year to first grade learners during the fundamental acquisitions stage. The application period was long-lasting, throughout the learning of reading and writing. The research methods used were observation, study of documents, psycho-pedagogical experiment, method of analysis of students' activity products and case study.

The development of reading comprehension skills starts from the preschool period and continues in the first years of schooling. We will present some absolutely necessary methods in this regard, methods that have been applied to first and second grade students.

The psycho-pedagogical experiment incorporated a set of activities that capitalized on specific methods for developing the comprehension of a text read. We will present some important and necessary aspects to be acquired by students in order to comprehend a text read. These aspects that have been taken into account since the acquisition of the first letters.

\section{Training of phonological awareness}

This constitutes a salient aspect and consists of developing and training learners' phonological consciousness. Following a synthesis study on maintaining the effects of training reading, Suggate (2016, in David \& Roșan, 2019, p. 19) reports that "phonological awareness training produced lasting effects $(\mathrm{M}=11$ months $)$, and the effect was transferred to other skills, for example comprehension."

Reading skills require action taken systematically and repeatedly which occurs before writing. At the beginning of the reading acquisition stage learners perceive the units separated from the composition of the word. Thus, efforts are needed for their synthesis. Then the perception of the word becomes global and is generalized in the case of syntagmatic units. This stage of global perception is followed by analysis in order to achieve the decoding and understanding of the word. The automation of the reading is related to the global and syncretic perception of the reading, being influenced by the speed and the focus on the main ideas.

It is necessary to have some acquisitions before starting the phonological awareness training, namely those related 
to spatial notions and spatial orientation (sequence according to ordinal position) and hearing discrimination skills.

\section{Training comprehension of the read text}

The decoding and comprehension of the read text require linguistic, orthoepic, punctuation and interpretation knowledge. A good lexical skill is required, putting the imprint on the personality of the reader but also his age. As a result of reading, the visual attention increases, reaching a cursive and expressive reading, but also to the development of thinking, motivation and "multidimensional" language (Slama-Cazacu, 1999, in Burlea, 2007, p. 124). Of course, the comprehension of the text read also depends on the difficulty of the text, on the child's vocabulary, on the basis of the knowledge held and on the accuracy of the reading.

Teachers play a particularly important role in developing first grade learners' appropriate comprehensive skills. We will outline some aspects that must be taken into account. First, the texts chosen by the teacher must have two important characteristics, namely, to be cohesive and coherent. There must be links and meaning between the sentences in a text. The decoding of the words must be correct. If there is a word that learners do not understand, i.e. the comprehension of the sentence within a paragraph, then the understanding will be compromised, especially if that word is essential in the respective text. Also, the correct, coherent reading favors reading comprehension.

The connection made between the text read and the general knowledge that the reader has, generates the inferences that underlie reading comprehension. Studies by Barnes, Dennis \& Haefele-Kalvaitis (1996) show that inferences improve with age and inferences made by young children may be limited by the accessibility of relevant information.

Following the studies, Mih (2004) emphasizes the important role of the explicit instructions provided by the teacher, through which the students are asked to generate relevant and correct inferences. By acquiring the appropriate modalities for their elaboration, children will understand the demands of the task and the meaning of the text, skills that can be applied in the situation of reading texts and viewing films or even cartoons.

Another important aspect represented the use of interactive methods suitable to the content transmitted.

Strategies for understanding the text through interactive methods

Interactive methods stimulate learning, critical, creative thinking, intragroup and intergroup communication, collaboration, create learning situations based on direct cooperation and involvement (Dulamă et al., 2015, 2019). All of these develop the self-esteem of the student, motivating him / her for active participation and involvement in the task, promoting a positive attitude and, which is very important, tolerance and mutual respect (Ilovan et al., 2016).

We will mention only a few interactive methods that favor the teaching-learning process when studying a text read.

Group-led activity is a method that supports the comprehension of the text read by asking inferential questions (connection, anaphoric, elaboration, predictive, factual) corresponding to the read content, thus developing the student's ability to detect important details and process texts. It also emphasizes anticipation as an important aspect of reading, students using the knowledge they possess and critical thinking to generate new ideas.

Directed reading and thinking activity resembles group-led activity, except that this method emphasizes the prediction of what will happen or will continue in the story or informative text. Thus, it is recommended that the text contains surprise elements.

"I know / I want to know / I learned" is another method of developing the comprehension of a text read, generally with scientific, informational content, which guides the extended learning along several activities. The students are helped to formulate inferential questions corresponding to the text and which can be elaborated due to their curiosity, uncertainty regarding the understanding of a content etc.

Mutual teaching is a method of learning through cooperation, through which inferential questions, prediction, clarification and summary of the read text appear. Also, students learn the positive interdependence and development of interpersonal skills.

A search procedure is applied when the text has a more complex content, it is requested information related to the main idea, clarification of details, deductions, predictions.

Thinking aloud is useful when it is necessary for the teacher to demonstrate the interaction with the text during reading. The processes that take place during the reading of a text are modeled in such a way that the students understand the reader's way of thinking. The teacher will reveal to the students what happens in his mind during the reading, emphasizing the use of imagery, which by indirect effect keeps the attention and the deeper processing active. It is also known that imaging exercises are a support in reading activities during the first years of school.

Interactive methods are multiple and varied and their use for comprehending the text read depends on the creativity of the teacher and its content.

\section{Findings}

At the beginning of the second grade, after the psychopedagogical experiment, students in the experimental class 
were asked to read a text at first sight and answer in written form to different inferential questions, formulated by the teacher. These were incorporated in the design documents of the evaluation of the products of the activity.

As a result of applying the methods mentioned above to students in the first grades, the effects were visible. Through the exercises of phonological awareness training, working memory was trained, the students retained the correct order of the letters easier, assigning them the corresponding sounds, the correct division of the words in syllables, the memory of the first syllable and the generation of the following syllables in order to identify the words correctly.

By explaining and understanding the steps to be taken in order to comprehend a text read, school performance increases, a fact that was proven by the case studies performed.

Further on, we exemplify the progress made by the students participating in the case studies: Our subject, D.C. is dyslexic and reads more slowly, with stumbling blocks and returns to the text read. He managed to answer correctly to approximately $80 \%$ of the inferential questions asked, erroneous answers being found to the questions regarding the connection inferences. Also, T.C and A.P, who come from disadvantaged families, learned to read and write. They answered correctly to $90 \%$ and $80 \%$ of the questions asked after reading a text at first sight. D.C who has elements specific to the attention deficit, managed to answer correctly to $76 \%$ of the questions, while the wrong answers occurred in questions related to connection inferences and, in part, to the ones concerning the elaboration inferences.

Also, the use of interactive strategies involves the students in activities through active participation, asking them to solve tasks, determining students' self-esteem as an outcome of the success achieved. It can be said that interactive methods have energized the teaching-learning process and motivated the students. These methods develop the ability to communicate and cooperate, the skills of networking and teamwork, positive attitudes and adaptability, involvement and responsibility.

\section{Conclusion}

The use of the interactive strategies from the psychopedagogical experiment involved the students in activities through active participation. By asking them to solve the tasks it determined an increase in self-esteem. It can be said that interactive methods have energized the teachinglearning process and motivated students.

These methods develop the ability to communicate and cooperate, networking and teamwork skills, positive attitudes and adaptability, involvement and responsibility.

By referring to the research question, we can conclude that the development of reading comprehension skills is favored by the use of teaching strategies appropriate to the particularities of students.

In a world full of stimuli, focusing children's attention on reading is useful and necessary for developing the skills of receiving the written message. The development of the comprehension of a read text depends, to a large extent, on the applied methods, on the tasks and texts used by the teacher. The efficiency of the didactic steps taken in order to train comprehension skills is determined by the existence of the skills of reading, analyzing and interpreting a text. The modeling occupies an important role in the development of the reading comprehension, the students being determined to participate actively in order to identify any existing ambiguities so that they can subsequently read on their own and apply the acquired skills. Applying in a suitable manner to the potential of the students in the classroom, the hidden curriculum will determine the development of the comprehension skills of the read text at its own pace, specific to the particular psychological particularities of the students.

Authors note: The authors have equal contributions to this article.

Chiș Olga is a senior lecturer at the Department of Educational Sciences, Babeș-Bolyai University, ClujNapoca, Romania. She graduated Ph.D. in educational sciences and her fields of interest include: parental education, children's literacy, assessment of children in kindergarten and primary school.

Grec Claudia graduated with a $\mathrm{PhD}$ in education sciences from Babeș-Bolyai University, Cluj-Napoca, Romania. She is an associate lecturer at the Department of Education Sciences, Babeș-Bolyai University, Cluj-Napoca, Romania, speech therapist at the School Center for Inclusive Education no. 1 from Tîrgu Mureş, 25 years old and member of the Romanian College of Psychologists. Her areas of interest are inclusive education, pedagogical intervention in learning difficulties, speech therapy.

\section{References}

Barnes, M.A, Dennis, M. \& Haefele-Kalvaitis, J. (1996). The effects of knowledge availability and knowledge accesibility on coherence and elaborative inferencing in children from six to fifteen years of age, in Journal of Experimental Child Psychology, 61: 216-41.

Bocoș, M.-D. (2013). Instruirea interactivă. Repere pentru reflecţie şi acţiune. Iași: Editura Polirom.

David, C. \& Roșan, A. (2019). Intervenții psihopedagogice in tulburările specifice de invățare: învățăm fonologic - program structurat de antrenament al conștiinței fonologice bazat pe dovezi științifice. Iași: Editura Polirom. 
Dulamă, M.E. \& Ilovan, O.-R. (2015). Development of the Geography school curriculum inRomania, from the 18th century to 1989. Transylvanian Review. 24(Supplement 1), 255-284.

Dulamă, M.E. \& Ilovan, O.-R. (2017). Development of geographical education in Romania, under the influence of the Soviet education model (1948-1962). Transylvanian Review, XXVI(1), 3-17.

Dulamă, M.E., Ilovan, O.-R., Bagoly-Simó, P. \& Magdaș, I. (2019). Development of the geographical education system in Romania, under the impact of World War II and during the transition to communism. Transylvanian Review. 24 (Supplement 2) - under print.
Dulamă, M.E., Ilovan, O.-R., Ciascai, L. \& Maroși, Z. (2015). E-learning Geography. How powerful is Facebook for Geography university students? Proceeding of the 10th International Conference on Virtual Learning. pp. 121-127.

Ilovan, O.-R., Jordan, P., Havadi-Nagy, K.X. \& Zametter, T. (2016). Identity matters fordevelopment: Austrian and Romanian experiences. Transylvanian Review. 25 (Supplement 1), 261-276.

Mih, V. (2004), Ințelegerea textelor. Strategii și mecanisme cognitive. Aplicații în domeniul educațional. ClujNapoca: Editura ASCR. 